\title{
Pengaruh Sekam Bakar dan Pupuk NPK Pada Pertumbuhan Bibit Lada
}

\section{The Effect of Roasted Husks and NPK Fertilizer on Growth of Pepper}

\section{Made Same dan Adryade Reshi Gusta*}

\author{
${ }^{1,2}$ Produksi Perkebunan Politeknik Negeri Lampung
}

*E-mail : adryade@polinela.ac.id

\begin{abstract}
Pepper is a plant that need nutrients in relatively large amounts. To obtain high growth rates and yields is needed a high fertilizer dosage with a balanced composition of the elements. One of the obstacles in the growth of pepper seeds is the lack of nutrients in the soil. For plantsnutrients, it is needed applying fertilizers in accordance with the right dose so that it is expected that the growth of pepper plants can increase.The research is increased vegetative growth of pepper seeds. The research was conducted at the Nursery Field and the State of Polytechnic Analysis Laboratory in April until October 2019.This study used randomized complete design. The first factor is granting of roasted husks consisting of three levels, $S_{0}=$ control, $S_{1}=$ media with soil and roasted husks (3:1), $S_{2}=$ media with soil and roasted husks (2:2). The second factor is four levels of NPK Mutiara fertilizer, control, NPK Mutiara fertilizer1,5 g/polybag, NPK Mutiara fertilizer3 g/polybag, NPK Mutiara fertilizer4,5 g/polybag. Each treatment was repeated three times, so 36 unit experiments were obtained. The results showed the roasted husksis had no effect on the growth of pepper seedlings. NPK Mutiara fertilizer with $4.5 \mathrm{~g} /$ polybag has a significant effect on the totally of leaves and totally of branches. There was no interaction between grilling of roasted husks and NPK Mutiara on the growth of pepper seedlings.
\end{abstract}

Keyword : NPK fertilizer, pepper seedlings and roasted husks

Disubmit: 7 Oktober 2019; Diterima: 20 November 2019; Disetujui: 08 Desember 2019

\section{PENDAHULUAN}

Lada merupakan komoditi ekspor terpenting setelah karet, minyak sawit, kopi, teh, dan tembakau. Kedudukannya sebagai komoditi ekspor perkebunan Indonesia tidak dapat diabaikan sebagai salah satu penambah devisa negara. Saat ini Indonesia termasuk negara produsen lada kedua di dunia di bawah Vietnam. Daerah penghasil lada utama di Indonesia adalah Lampung dan Bangka. Kebutuhan lada baik lada hitam maupun lada putih, semakin meningkat. Hal ini disebabkan oleh pertumbuhan penduduk, perluasan bidang kegunaan, dan perluasan daerah pemasarannya.

Tanaman lada merupakan salah satu komoditas unggulan di Provinsi Lampung dan menghasilkan devisa negara dan sumber pendapatan bagi banyak petani. Luas areal tanaman lada di Provinsi Lampung pada tahun 2016 seluas 76.509 ha dengan produksi sebesar 30.198 ton.

Lada merupakan tanaman yang membutuhkan unsur hara dalam jumlah yang relatif banyak. Untuk memperoleh tingkat pertumbuhan dan hasil yang tinggi diperlukan dosis pemupukan yang tinggi dengan komposisi unsur yang berimbang.

Salah satu hambatan dalam pertumbuhan bibit lada adalah kurang tersedianya unsur hara dalam tanah. Untuk memenuhi kebutuhan unsur hara bagi tanaman dilakukan dengan pemberian pupuk yang sesuai dengan dosis yang tepat sehingga diharapkan pertumbuhan tanaman lada dapat meningkat (Martin, A. B., M. Same, 2015). Salah satu alternatif pemecahan yang diusahakan adalah dengan budidaya lada yang ditunjang dengan 
tindakan-tindakan budidaya, antara lain penggunaan bibit unggul, pemupukan, pengairan, pengendalian hama dan penyakit dilakukan dengan optimal sehingga sangat diharapkan meningkatnya produktivitas lada yang dihasilkan. Pada pemupukan tanaman lada adalah dengan usaha pemanfaatan pupuk organik dan pupuk majemuk. Selama ini pemupukan tanaman lada lebih banyak menggunakan pupuk tunggal. Penggunaan pupuk majemuk mempunyai keunggulan daripada pupuk tunggal seperti halnya dalam keefisienan waktu kerja yang lebih cepat sehingga dapat menekan biaya produksi lebih rendah.

Upaya yang dapat dilakukan untuk meningkatkan tingkat produktivitas lahan kering salah satu diantaranya adalah dengan pemberian bahan organik(Hakim, dkk, 1986; Leiwakabessy, 1992). Menurut Basa, I. E. Suhartatik, (1992) bahwa pemberian bahan organik diharapkan dapat mendukung peningkatan produktivitas lahan kering karena bahan organik mempunyai kemampuan untuk memperbaiki sifat fisik, kimia dan biologis tanah.

Salah satu jenis pupuk organik yang diharapkan dapat memperbaiki sifat-sifat tanah dan hasil tanaman adalah sekam bakar. Sekam bakar merupakan media tanam yang porous dan steril dari sekam padi dengan cara membakar kulit padi kering di atas tungku pembakaran, dan sebelum bara sekam menjadi abu disiram dengan air bersih. Hasil yang diperoleh berupa arang sekam atau sekam bakar. Selanjutnya Supriati, (2011) mengemukakan arang sekam adalah sekam padi yang telah dibakar dengan pembakaran tidak sempurna. Cara pembuatannya dapat dilakukan dengan menyangrai atau membakar.

Keunggulan sekam bakar adalah dapat memperbaiki sifat fisik dan kimia tanah. Sekam bakar yang digunakan adalah hasil pembakaran sekam padi yang tidak sempurna, sehingga diperoleh sekam bakar yang berwarna hitam, dan bukan abu sekam yang bewarna putih (Supriati, 2011). Selanjutnya Gustia, (2013) menambahkan sekam padi memiliki aerasi dan drainasi yang baik, tetapi masih mengandung organismeorganisme pathogen atau organisme yang dapat menghambat pertumbuhan tanaman. Oleh sebab itu sebelum menggunakan sekam sebagai media tanam, maka untuk menghancurkan patogen sekam tersebut dibakar terlebih dahulu.

Untuk mendapatkan bibit yang memiliki performa yang baik diperlukan media tanam yang baik untuk pertumbuhan bibit lada. Untuk memenuhi kebutuhan unsur hara bagi tanaman dilakukan dengan pemberian sekam bakar untuk memperbaiki sifat fisik, kimia, dan biologi tanah. Sedangkan untuk menambah unsur hara makro seperti unsur N, P, dan K dilakukan dengan menambahkan pupuk NPK Mutiara sesuai dengan dosis yang tepat sehingga diharapkan pertumbuhan bibit lada dapat meningkat.

Penggunaan sekam bakar dan pupuk majemuk dalam bidang pertanian menunjukkan prospek yang cerah dilihat dari tingkat keberhasilan penanaman di lahan yang sangat marjinal seperti kekurangan unsur hara dan air, bekas alang-alang, lahan bekas kebakaran, dan lahan terbuka lainnya. Beberapa penelitian telah menunjukkan manfaat pupuk organik dan pupuk majemuk dalam meningkatkan pertumbuhan dan produksi seperti pada tanaman bibit sawit (Siallagan, 2014) tanaman jagung manis (Rahmah, Izzati, \& Parman, 2014), ubi kayu (Prasetyo, Utomo, \& Listyorini, 2014)kacang panjang (Zaevie, B., N. Marisi, 2014) bibit kakao (Christina, dkk 2013)

\section{METODE PENELITIAN}

Penelitian dilaksanakan pada bulan April sampai dengan Oktober 2019 di Kebun Pembibitan dan Laboratorium Analisis Politeknik Negeri Lampung. Alat yang digunakan adalah Chlorophyll Meter SPAD 502, cangkul, sprayer, gembor, ember, meteran, palu, golok, oven, alat pengukur, alat tulis, dan timbangan. Sedangkan bahan yang digunakan adalah setek sulur panjat lada, pupuk organik berupa sekam bakar, pupuk majemuk NPK Mutiara, polibeg, kantong plastik, kantong kertas, bambu, shading net, paku, label, pestisida, growtone, tali rafia, dan ajir.

Perlakuan disusun secara faktorial dalam Rancangan Acak Kelompok. Faktor pertama adalah pemberian sekam bakar yang terdiri dari tiga taraf yaitu media tanam hanya menggunakan tanah (sebagai 
kontrol), media tanam dengan perbandingan tanah dan sekam bakar 3:1, media tanam dengan perbandingan tanah dan sekam bakar 2:2. Faktor kedua adalah empat taraf pupuk NPK yang dalam penelitian ini menggunakan pupuk NPK Mutiara yaitu tanpa pemberian NPK Mutiara (Kontrol), pemberian NPK Mutiara 1,5 g/polibag, pemberian NPK Mutiara $3 \mathrm{~g} /$ polibeg, dan pemberian NPK Mutiara 4,5 g/polibeg. Setiap perlakuan diulang tiga kali, sehingga diperoleh 36 satuan percobaan. Masing-masing satuan percobaan terdapat lima bibit lada yang akan dijadikan sebagai sampel.

Analisis data dilakukan dengan sidik ragam dan nilai tengah antar perlakuan diuji menggunakan BNT (Beda Nyata Terkecil) pada tingkat ketelitian 5\%.

Lahan yang digunakan untuk penelitian dibersihkan dengan menggunakan cangkul yaitu dengan mengangkat semua gulma yang ada dan membuang sisa tanaman dari lahan tersebut sampai lahan benar-benar bersih. Selanjutnya pembuatan bedengan dan naungan dari atap shading net yang berfungsi untuk melindungi bibit dari sinar matahari langsung dan percikan air hujan. Di dalam bedengan dipasang sungkup dari plastik berwarna putih untuk menjaga kelembaban agar tetap tinggi. Naungan dibuat menghadap timur barat dengan tinggi naungan sebelah timur $2 \mathrm{~m}$ dan sebelah barat $2 \mathrm{~m}$ dan seluruh naungan diberi dinding menggunakan shading net.

Setek lada yang digunakan dalam penelitian ini adalah setek dari sulur panjat varietas Natar 1. Setek lada dibuat dengan cara memotong miring bagian pupuk cabang buah sebanyak 1 ruas berdaun tunggal.

Media yang digunakan untuk pembibitan lada adalah tanah lapisan atas yang diambil dari kebun Politeknik Negeri Lampung yang diayak sehingga butiran tanahnya seragam serta tidak terdapat bekas sisa tanaman dan pengambilan tanah lapisan atas dilakukan pada satu titik.

Pemberian pupuk organik berupa sekam bakar dilakukan dengan cara mencampurkannya ke dalam media tanam sesuai dengan perbandingan yang telah ditentukan untuk masing-masing perlakuan. Media tanam yang telah tercampur dimasukkan dalam polibeg dengan ukuran diameter $15 \mathrm{~cm}$ dan tinggi $20 \mathrm{~cm}$. Penanaman setek lada dilakukan dengan cara membuat lubang tanam dalam polibeg sedalam sekitar $7 \mathrm{~cm}$, kemudian setek lada ditanam dan media tanam dipadatkan. Untuk memudahkan pembuatan lubang tanam sebelumnya tanah dibasahi dengan air. Setelah kegiatan penanaman selesai, selanjutnya disiram menggunakan larutan DithaneM45 sebanyak $2 \mathrm{~g} /$ liter air yang berfungsi untuk mencegah cendawan.

Pemberian pupuk NPK Mutiara dilakukan dengan cara membuat lubang melingkari bibit dengan jarak $2 \mathrm{~cm}$ dari tanaman dan pupuk ditaburkan merata pada lubang kemudian ditutup dengan tanah. Pemberian pupuk NPK Mutiara dilakukan pada saat tanaman berumur 1 bulan dengan dosis sesuai perlakuan. Untuk menjaga agar bibit tumbuh dan berkembang dengan baik maka dilakukan pemeliharaan seperti penyiraman, penyiangan, serta pengandalian hama dan penyakit. Peubah yang diamati dari penelitian ini meliputi: (a) Tinggi bibit $(\mathrm{cm})$. Tinggi bibit diukur dari permukaan tanah sampai ke ujung daun tertinggi. Pengukuran dilakukan pada akhir penelitian; (b) Jumlah daun bibit (helai). Jumlah daun dihitung dengan cara menghitung semua daun yang telah membuka sempurna. Pengukuran dilakukan pada akhir penelitian.; (c) Jumlah ruas (helai). Jumlah ruas dihitung dengan cara menghitung semua ruas. Pengukuran dilakukan pada akhir penelitian ; (d) Jumlah cabang primer. Perhitungan didasarkan pada jumlah cabang yang keluar dari batang utama; (e) Bobot kering akar $(\mathrm{g})$. Akar dikeringkan dalam oven selama 48 jam dengan suhu $70{ }^{\circ} \mathrm{C}$, lalu ditimbang. Pengukuran dilakukan pada akhir penelitian; (f) Bobot kering brangkasan (g). Brangkasan dikeringkan dalam oven selama 48 jam dengan suhu $70{ }^{\circ} \mathrm{C}$, lalu ditimbang. Pengukuran dilakukan pada akhir penelitian; (g) Jumlah Klorofil. Pengamatan dilakukan pada daun ketiga dari pucuk menggunakan alat Chlorophyll Meter SPAD 502. 


\section{HASIL DAN PEMBAHASAN}

Hasil analisis ragam menunjukkan tidak terdapat interaksi yang nyata antara sekam bakar dan pupuk NPK Mutiara pada pertumbuhan bibit lada. Analisis ragam pemberian sekam bakar tidak berbeda nyata terhadap pertumbuhan bibit lada, akan tetapi dosis NPK Mutiara berbeda nyata terhadap pertumbuhan bibit lada.

Pengaruh Sekam Bakar pada Pertumbuhan Bibit Lada. Hasil analisis data (uji BNT) menunjukkan media tanam hanya menggunakan tanah (sebagai kontrol), media tanam dengan perbandingan tanah dan sekam bakar 3:1, dan media tanam dengan perbandingan tanah dan sekam bakar 2:2 menghasilkan rerata tinggi bibit, jumlah daun, jumlah ruas, jumlah cabang, bobot kering akar, bobot kering brangkasan, dan jumlah klorofil tidak berbeda nyata (Tabel 1).

Tabel 1. Nilai rerata pengaruh sekam bakar pada tinggi bibit, jumlah daun, jumlah ruas, jumlah cabang, bobot kering akar, bobot kering brangkasan, dan jumlah klorofil

\begin{tabular}{lccccccc}
\hline \multicolumn{1}{c}{ Perlakuan } & $\begin{array}{c}\text { Tinggi } \\
\text { Bibit (cm) }\end{array}$ & $\begin{array}{c}\text { Jumlah } \\
\text { Daun } \\
\text { (helai) }\end{array}$ & $\begin{array}{c}\text { Jumlah } \\
\text { Ruas (helai) }\end{array}$ & $\begin{array}{c}\text { Jumlah } \\
\text { cabang }\end{array}$ & $\begin{array}{c}\text { Bobot } \\
\text { Kering } \\
\text { Akar (g) }\end{array}$ & $\begin{array}{c}\text { Bobot Kering } \\
\text { Brangkasan (g) }\end{array}$ & $\begin{array}{c}\text { Jumlah } \\
\text { Klorofil }\end{array}$ \\
\hline $\begin{array}{l}\text { Media } \\
\text { anah } \\
\text { (kontrol) }\end{array}$ & $25,07 \mathrm{a}$ & $7,36 \mathrm{a}$ & $8,33 \mathrm{a}$ & $0,42 \mathrm{a}$ & $0,42 \mathrm{a}$ & $2,13 \mathrm{a}$ & $42,20 \mathrm{a}$ \\
$\begin{array}{l}\text { Media tanah } \\
\text { dan sekam bakar }\end{array}$ & $26,13 \mathrm{a}$ & $8,44 \mathrm{a}$ & $9,47 \mathrm{a}$ & $0,50 \mathrm{a}$ & $0,52 \mathrm{a}$ & $2,05 \mathrm{a}$ & $42,13 \mathrm{a}$ \\
$\begin{array}{l}3: 1) \\
\begin{array}{l}\text { Media tanah } \\
\text { dan sekam bakar } \\
(2: 2)\end{array}\end{array}$ & $28,36 \mathrm{a}$ & $7,69 \mathrm{a}$ & $9,42 \mathrm{a}$ & $0,47 \mathrm{a}$ & $0,48 \mathrm{a}$ & $2,07 \mathrm{a}$ & $36,73 \mathrm{a}$ \\
\hline
\end{tabular}

Keterangan: Angka-angka yang diikuti oleh huruf yang sama pada kolom yang sama menunjukkan tidak berbeda nyata pada taraf 5\% uji Beda Nyata Terkecil

Secara statistik perlakuan sekam bakar memberikan hasil yang tidak nyata, namun terdapat tendensi semakin meningkat komposisi sekam yang diberikan maka semakin meningkat pula pertumbuhan bibit lada. Hal ini dapat di duga bahwa pemberian pupuk organik pada pembibitan lada mampu memperbaiki kondisi lingkungan bagi pertumbuhan bibit lada. Sebagaimana dikatakan oleh Marsono dan P. Sigit., (2008) bahwa kelebihan organik adalah mampu merubah struktur tanah menjadi lebih baik bagi perkembangan perakaran, meningkatkan daya pegang dan daya serap tanah terhadap air, memperbaiki kehidupan organisme dalam tanah dan menambah unsur hara di dalam tanah.

Usaha yang dilakukan untuk memperbaiki kesuburan tanah adalah dengan melakukan pemupukan menggunakan pupuk organik. Kandungan unsur hara dalam pupuk kandang tidak terlalu tinggi, tetapi jenis pupuk ini mempunyai lain yaitu dapat memperbaiki sifat-sifat fisiktanah seperti permeabilitas tanah, porositastanah, struktur tanah, daya menahan air dan kation kation tanah. (Roidah, 2013). Secara umum setiap ton pupuk kandang mengandung $5 \mathrm{~kg} \mathrm{~N}, 3 \mathrm{~kg} \mathrm{P} 2 \mathrm{O} 5$ dan $5 \mathrm{~kg} \mathrm{~K} 2 \mathrm{O}$ serta unsur-unsur hara esensial lain dalam jumlah yang relatif kecil (Hardjowigeno, 2010).

Salah satu jenis pupuk organik yang diharapkan dapat memperbaiki sifat-sifat tanah dan hasil tanaman adalah sekam bakar. Secara umum, media tanam harus dapat menjaga kelembaban daerah sekitar akar, menyediakan cukup udara, dan dapat menahan ketersediaan unsur hara. Sekam bakar sebagai salah satu bahan organik merupakan media tanam yang dapat menjaga kelembaban. Hal ini disebabkan sekam bakar lebih porous karena memiliki pori-pori makro dan mikro yang hampir seimbang, sehingga sirkulasi udara yang dihasilkan cukup baik serta memiliki daya serap air yang tinggi (Wuryan, 2012)

Bahan organik akan mengalami proses pelapukan atau dekomposisi yang dilakukan oleh mikroorganisme. Melalui proses tersebut, akan dihasilkan karbondioksida $\left(\mathrm{CO}_{2}\right)$, air $\left(\mathrm{H}_{2} \mathrm{O}\right)$, dan mineral. 
Mineral yang dihasilkan merupakan sumber unsur hara yang dapat diserap tanaman sebagai zat makanan (Wuryan, 2012).

Perkembangan jaringan tanaman sangat dipengaruhi oleh unsur hara makro dan mikro serta media tanam. Unsur hara mikro Ca dibutuhkan antara lain dalam mengaktifkan sejumlah enzim yang berfungsi dalam mitosis, pembelahan sel, sintesis protein dan trasnlokasi karbohidrat. Tingkat pertumbuhan antara akar dengan pohon (batang, cabang, tajuk) secara fisiologis pada dasarnya terdapat keseimbangan, sehingga suplai hara akan sesuai dengan kebutuhan (Hakim, dkk, 1986).

Tanaman yang terpenuhi kebutuhan unsur haranya, akan dapat merangsang pertumbuhan daun baru. Menurut Hardjowigeno (2010), tanaman yang cukup mendapat nitrogen dalam tanah akan tumbuh lebih hijau. Hasil penelitian pada pembibitan lada menunjukkan bahwa pemberian pupuk kandang sapi $100 \mathrm{~g}$ tiap polibeg berpengaruh nyata pada pertumbuhan bibit lada (Same, 2018).

Menurut Wuryan, (2012) sekam bakar memiliki karakteristik yang istimewa, oleh karena itu dapat dimanfaatkan sebagai media tanam untuk hidroponik Komposisi kimiawi sekam bakar adalah $\mathrm{SiO}_{2}$ dengan kadar 52\% dan $\mathrm{C}$ sebanyak $31 \%$. Sementara kandungan lainnya terdiri dari $\mathrm{Fe}_{2} \mathrm{O}_{3}, \mathrm{~K}_{2} \mathrm{O}, \mathrm{MgO}, \mathrm{CaO}, \mathrm{MnO}$, dan $\mathrm{Cu}$ dengan jumlah yang kecil serta beberapa bahan organik lainnya.

Sebagai media tanam, sekam bakar berperan penting dalam perbaikan sifat fisik, sifat kimia, dan melindungi tanaman (Gustia, 2013). Kondisi ini akan berdampak positif terhadap pertumbuhan dan perkembangan tanaman sawi, dimana perakaran akan berkembang dengan baik sehingga pengambilan hara oleh akar akan optimal.

Pengaruh Pupuk NPK pada Pertumbuhan Bibit Lada. Hasil analisis data (uji BNT) menunjukkan bahwa pupuk NPK Mutiara 4,5 g-1 polibeg menghasilkan rerata jumlah daun dan jumlah cabang berbeda nyata dibandingkan dengan perlakuan lainnya. Akan tetapi perlakuan pupuk NPK Mutiara menghasilkan rerata tinggi bibit, jumlah ruas, bobot kering akar, bobot kering brangkasan, dan jumlah klorofil tidak berbeda nyata (Tabel 2).

Tabel 2. Nilai rerata pengaruh pupuk NPK pada tinggi bibit, jumlah daun, diameter batang, jumlah cabang, bobot kering akar, bobot kering brangkasan, dan jumlah klorofil

\begin{tabular}{lccccccc}
\hline \multicolumn{1}{c}{ Perlakuan } & $\begin{array}{c}\text { Tinggi } \\
\text { Bibit } \\
(\mathrm{cm})\end{array}$ & $\begin{array}{c}\text { Jumlah } \\
\text { Daun } \\
\text { (helai) }\end{array}$ & $\begin{array}{c}\text { Jumlah } \\
\text { Ruas } \\
\text { (helai) }\end{array}$ & $\begin{array}{c}\text { Jumlah } \\
\text { cabang }\end{array}$ & $\begin{array}{c}\text { Bobot } \\
\text { Kering } \\
\text { Akar }(\mathrm{g})\end{array}$ & $\begin{array}{c}\text { Bobot Kering } \\
\text { Brangkasan (g) }\end{array}$ & $\begin{array}{c}\text { Jumlah } \\
\text { Klorofil }\end{array}$ \\
\hline $\begin{array}{l}\text { NPK Mutiara } 0 \mathrm{~g}^{-1} \\
\text { polibag }\end{array}$ & $19,77 \mathrm{~b}$ & $6,41 \mathrm{~b}$ & $6,85 \mathrm{~b}$ & $0,33 \mathrm{~b}$ & $0,54 \mathrm{a}$ & $1,73 \mathrm{a}$ & $37,31 \mathrm{a}$ \\
$\begin{array}{l}\text { NPK Mutiara } 1,5 \\
\mathrm{~g}^{-1} \text { polibag }\end{array}$ & $29,45 \mathrm{a}$ & $7,93 \mathrm{ab}$ & $9,78 \mathrm{a}$ & $0,44 \mathrm{~b}$ & $0,50 \mathrm{a}$ & $2,10 \mathrm{a}$ & $41,49 \mathrm{a}$ \\
$\begin{array}{l}\text { NPK Mutiara } 3 \mathrm{~g}^{-1} \\
\text { polibag }\end{array}$ & $29,83 \mathrm{a}$ & $7,93 \mathrm{ab}$ & $9,52 \mathrm{a}$ & $0,33 \mathrm{~b}$ & $0,49 \mathrm{a}$ & $2,19 \mathrm{a}$ & $42,62 \mathrm{a}$ \\
$\begin{array}{l}\text { NPK Mutiara 4,5 } \\
\mathrm{g}^{-1} \quad \text { polibag }\end{array}$ & $27,02 \mathrm{a}$ & $9,07 \mathrm{a}$ & $10,15 \mathrm{a}$ & $0,74 \mathrm{a}$ & $0,37 \mathrm{a}$ & $2,32 \mathrm{a}$ & $39,99 \mathrm{a}$ \\
\hline
\end{tabular}

Keterangan: Angka-angka yang diikuti oleh huruf yang sama pada kolom yang sama menunjukkan tidak berbeda nyata pada taraf $5 \%$ uji Beda Nyata Terkecil

Jumlah daun bibit lada dan jumlah cabang memberikan hasil yang nyata. Akan tetapi tinggi bibit, jumlah daun, bobot kering akar, bobot kering brangkasan, dan jumlah klorofil memberikan hasil yang tidak nyata tetapi ada tendensi bahwa semakin meningkat dosis pupuk NPK Mutiara yang diberikan maka semakin meningkat pula pertumbuhan bibit lada. Hal ini disebabkan bahwa dengan semakin dewasanya tanaman, maka sistem perakaran telah berkembang dengan baik dan lengkap, sehingga tanaman semakin mampu menyerap unsur hara dalam bentuk anion dan kation yang mengandung unsur N, P dan K yang terdapat pada pupuk Mutiara tersebut. Banyaknya unsur hara yang dapat diserap oleh tanaman, maka pertumbuhan dan 
perkembangan tanaman semakin meningkat. Bila dosis pupuk ditingkatkan, maka ada kecenderungan peningkatan pertumbuhan bibit lada, sesuai dengan pendapat Mulyani, (2008) bahwa untuk pertubuhann vegetatif dan generatif tanaman diperlukan unsur-unsur hara terutama $\mathrm{N}, \mathrm{P}$ dan $\mathrm{K}$. Unsur $\mathrm{N}$ diperlukan untuk pembentukan karbohidrat, protein, lemak dan persenyawaan organik lainnya.

Penggunaan pupuk anorganik sebaiknya disertai dengan pemberian pupuk organik sebagai pelengkap dan penyeimbang penggunaan pupuk anorganik. Penggunaan pupuk organik dapat memperbaiki sifat fisik, kimia dan biologi tanah, serta membantu melepaskan unsur hara dari ikatan koloid tanah. Selain itu, unsur hara yang mudah hilang akibat penguapan atau terbawa perkolasi, dengan adanya pupuk organik unsur hara tersebut akan diikat sehingga tidak mudah tercuci dan dapat tersedia bagi tanaman (Paramananthan, 2013)

Menurut Siallagan, (2014) pupuk organik dan NPK majemuk meningkatkan pertumbuhan tinggi tanaman dan lingkar batang kelapa sawit belum menghasilkan. Pupuk organik dan NPK majemuk berpengaruh nyata terhadap kadar $\mathrm{N}$ dan $\mathrm{P}$ daun kelapa sawit namun tidak berpengaruh nyata terhadap kadar $\mathrm{K}$ daun, kadar klorofil daun dan kerapatan stomata.

Hasil penelitian pada kacang panjang menunjukkan bahwa respon tanaman kacang panjang terhadap pemberian pupuk NPK pelangi pada semua variabel pengukuran menunjukan hasil berbeda sangat nyata seperti jumlah polong per tanaman, berat polong per tanaman, panjang polong per tanaman dan hasil polong per tanaman (Zaevie, B., N. Marisi, 2014).

Berdasarkan hasil penelitian Siallagan, (2014) pupuk organik dan NPK majemuk meningkatkan pertumbuhan tinggi tanaman dan lingkar batang kelapa sawit belum menghasilkan dan berpengaruh nyata mulai8 BSP. Interaksi pupuk organik dan NPK majemuk tidak berpengaruh nyata terhadap peubah panjang pelepah, jumlah pelepah dan luas daun. Pupuk organik dan NPK majemuk berpengaruh nyata terhadap kadar $\mathrm{N}$ dan $\mathrm{P}$ daun kelapa sawit namun tidak berpengaruh nyata terhadap kadar $\mathrm{K}$ daun, kadar klorofil daun dan kerapatan stomata. Berdasarkan peubah tinggi tanaman dan lingkar batang, dosis optimum pupuk organik adalah $40.7 \mathrm{~kg}$ tanaman-1 dan untuk pupuk NPK majemuk adalah $1.9 \mathrm{~kg}$ tanaman-1 pada tanaman kelapa sawit belum menghasilkan umur satu tahun.

Pengaruh Interaksi Sekam Bakar dan NPK pada Pertumbuhan Bibit Lada. Hasil analisis ragam menunjukkan bahwa Interaksi antara sekam bakar dan NPK Mutiara berpengaruh tidak nyata pada tinggi bibit, jumlah daun, jumlah ruas, jumlah cabang, bobot kering akar, bobot kering brangkasan, dan jumlah klorofil. Hal ini di duga bahwa masing-masing faktor perlakuan pada taraf perlakuannya tidak saling berinteraksi.

Penggunaan sekam bakar sebagai pupuk organik dan pupuk majemuk dalam bidang perkebunan menunjukkan prospek yang cerah dilihat dari tingkat keberhasilan penanaman di lahan yang sangat marjinal seperti kekurangan unsur hara dan air, bekas alang-alang, lahan bekas kebakaran, dan lahan terbuka lainnya.

Penggunaan pupuk anorganik sebaiknya disertai dengan pemberian pupuk organik sebagai pelengkap dan penyeimbang penggunaan pupuk anorganik. Penggunaan pupuk organik dapat memperbaiki sifat fisik, kimia dan biologi tanah, serta membantu melepaskan unsur hara dari ikatan koloid tanah. Selain itu, unsur hara yang mudah hilang akibat penguapan atau terbawa perkolasi, dengan adanya pupuk organik unsur hara tersebut akan diikat sehingga tidak mudah tercuci dan dapat tersedia bagi tanaman (Paramananthan, 2013)

Menurut Siallagan, (2014) pupuk organik dan NPK majemuk meningkatkan pertumbuhan tinggi tanaman dan lingkar batang kelapa sawit belum menghasilkan. Pupuk organik dan NPK majemuk berpengaruh nyata terhadap kadar $\mathrm{N}$ dan $\mathrm{P}$ daun kelapa sawit namun tidak berpengaruh nyata terhadap kadar $\mathrm{K}$ daun, kadar klorofil daun dan kerapatan stomata.

Berdasarkan hasil penelitian Siallagan, (2014) pupuk organik dan NPK majemuk meningkatkan pertumbuhan tinggi tanaman dan lingkar batang kelapa sawit belum menghasilkan dan berpengaruh nyata mulai. Interaksi pupuk organik dan NPK majemuk tidak berpengaruh nyata terhadap peubah panjang pelepah, jumlah pelepah dan luas daun. Pupuk organik dan NPK majemuk berpengaruh nyata terhadap kadar $\mathrm{N}$ dan $\mathrm{P}$ 
Same, $M \&$ Gusta, A, R : Pengaruh Sekam Bakar Dan Pupuk NPK Pada Pertumbuhan Bibit Lada

daun kelapa sawit namun tidak berpengaruh nyata terhadap kadar K daun, kadar klorofil daun dan kerapatan stomata.

\section{KESIMPULAN}

Pemberian sekam bakar tidak berpengaruh pada pertumbuhan bibit lada, pupuk NPK Mutiara 4,5 g tiap polibeg berpengaruh nyata pada jumlah daun dan jumlah cabang, dan tidak terdapat interaksi antara sekam bakar dan NPK Mutiara pada pertumbuhan bibit lada.

\section{DAFTAR PUSTAKA}

Basa, I. E. Suhartatik, dan D. D. P. (1992). Bahan Organik untuk Stabilitas Produksi Tanaman Pangan pada Lahan Kering Podsolik. Prosiding Semnar Balittan, Bogor. Bogor.

Christina Desiana, Irwan Sukri Banuwa, Rusdi Evizal, S. Y. (2013). Pengaruh Pupuk Organik Cair Urin Sapi dan Limbah Tahu Terhadap Pertumbuhan Bibit Kakao ( Theobroma cacao L. ). Agrotek Tropika.

Gustia, H. (2013). Pengaruh Penambahan Sekam Bakar pada Media Tanam Terhadap Pertumbuhan dan Produksi Tanaman Sawi (Brassica juncea L.)". E-Journal WIDYA Kesehatan Dan Lingkungan. https://doi.org/10.1016/j.ocl.2008.05.004

Hakim, N., Y. Nyakpa, A. M. Lubis, S. G. Nugroho, M. R. Saul, M. A. Diha, G. B. Hong, dan H. H. B. (1986). Dasar-dasar Ilmu Tanah. Universitas Lampung. Bandar Lampung.

Leiwakabessy, F. M. dan A. S. (1992). Pupuk dan Pemupukan. Jurusan Ilmu Tanah, Faperta IPB. Bogor. Bogor.

Marsono dan P. Sigit. (2008). Pupuk Akar Jenis dan Aplikasi. Jakarta: Penebar Swadaya.

Martin, A. B., M. Same, dan W. I. (2015). Pengaruh Media Pembibitan pada Pertumbuhan Setek Lada (Piper nigrum L.). J. AIP, 3 (2), 94-107.

Mulyani, S. M. (2008). Pupuk dan Cara Pemupukan. Jakarta: Rineka Cipta. Jakarta.

Paramananthan, S. (2013). Managing Marginal Soils for Sustainable Growth of Oil Palms in the Tropics. Journal of Oil Palm and the Environment. https://doi.org/10.5366/jope.2013.1

Prasetyo, A., Utomo, W. H., \& Listyorini, E. (2014). Hubungan Sifat Fisik Tanah, Perakaran dan Hasil Ubi Kayu Tahun Kedua pada Alfisol Jatikerto akibat pemberian Pupuk Organik dan Anorganik. Jurnal Tanah Dan Sumber Daya Lahan.

Rahmah, A., Izzati, M., \& Parman, S. (2014). Pengaruh pupuk organik cair berbahan dasar limbah sawi putih (Brassica chinensis L.) terhadap pertumbuhan tanaman jagung manis (Zea mays L. var. Saccharata). Buletin Anatomi Dan Fisiologi.

Roidah, I. S. (2013). Manfaat Penggunaan Pupuk Organik Untuk Kesuburan Tanah. J. Universitas Tulungagung Bonorowo, 1 (1), 30-42.

Same, M. dan A. R. G. (2018). Pengaruh Pupuk Organik dan NPK Mutiara pada Pertumbuhan Bibit Lada. Prosiding Seminar Nasional Pengembanan Teknologi Pertanian Peran Penelitian Pertanian Untuk Mendukung Pengembangan Teknologi Pertanian. Bandar Lampung 2018. Halaman 439-446.

Siallagan, I. (2014). Optimasi Dosis Pupuk Organik dan NPK Majemuk pada Tanaman Kelapa Sawit Belum Menghasilkan Optimizing Rate of Organic and NPK Compound Fertilizers for Immature Oil Palm. Optimasi Dosis Pupuk Organik Dan NPK Majemuk Pada Tanaman Kelapa Sawit Belum Menghasilkan. 
Jurnal Penelitian Pertanian Terapan

Supriati, Y. dan E. H. (2011). Bertanam 15 Sayuran Organik dalam Pot. Jakarta: Penebar Swadaya.

Wuryan. (2012). Pengaruh Media Sekam Padi Terhadap Pertumbuhan Tanaman Hias Pot Spathiphyllum.

Zaevie, B., N. Marisi, dan P. A. (2014). Respon Tanaman Kacang Panjang (Vigna sinensis L.) Terhadap Pemberian Pupuk NPK Pelangi dan Pupuk Organik Cair Nasa. J. Agrifor, XIII (1), 19-32. 